EVIDENCE BASED PUBLIC HEALTH POLICY AND PRACTICE

\title{
Safer storage of firearms at home and risk of suicide: a study of protective factors in a nationally representative sample
}

\author{
Edmond D Shenassa, Michelle L Rogers, Kirsten L Spalding, Mary B Roberts
}

See end of article for

authors' affiliations

J Epidemiol Community Health 2004;58:841-848. doi: 10.1136/jech.2003.017343

Correspondence to:

Assistant Professor, E D

Shenassa, Department of

Community Health and

Centers for Behavioral and

Preventive Medicine,

Brown Medical School,

One Hoppin Street, Suite

500, Providence, RI

02903, USA;

Edmond_Shenassa@

Brown.edu

Accepted for publication

4 February 2004

\begin{abstract}
Objective: To estimate the protective effect of storing firearms locked or unloaded, or both, on the risk of suicide by firearms among people with relatively low intention to die.

Design and setting: Cross sectional survey. The 1993 National Mortality Followback Survey of 22957 deaths in the United States, representing 2.2 million people, conducted by the National Center for Health Statistics.

Participants: Decedent's next of kin answered questions regarding various aspects of decedent's life to supplement information from death certificates.

Main results: Compared with decedents who stored their firearm unlocked or loaded, those who stored their firearms locked or unloaded, or both, were less likely to commit suicide by firearms (locked: $\mathrm{OR}=0.39,95 \% \mathrm{Cl}=0.24$ to 0.66 ; unloaded $\mathrm{OR}=0.30,95 \% \mathrm{Cl}=0.18$ to 0.49 ).

Conclusions: This study further supports the utility of devices and practices intended to reduce the likelihood of unauthorised or impulsive use of firearms.
\end{abstract}

$\mathrm{R}$ eady access to firearms at home is an international phenomenon. Many nations, both developing and developed, have high levels of per capita firearm ownership. ${ }^{2}$ In the US, where $41 \%$ to $49 \%$ of households own a firearm, about $75 \%$ of handgun owners and $38 \%$ of all firearm owners claim protection of themselves, their families, and their property as the main reason for storing firearms at home..$^{3-5}$ However, far from being a source of protection, access to firearms at home has been repeatedly linked with household members' risk of violent death. ${ }^{6-11}$ This link is particularly well reported for suicide. Ecological studies (table 1) have consistently linked state, regional, and national levels of firearm availability with firearm related suicide rates among various demographic groups ${ }^{212-28}$ as well as overall suicide rates, ${ }^{2} 121820212324$ particularly among people under age 25.222329

More convincingly, individual level studies also evince a link between firearm ownership and risk of suicide (table 2). Among adults, purchase of a handgun is linked with an increased risk of suicide, an association that can persist for five years after the purchase. ${ }^{30-32}$ On the balance, individual level studies also suggest a positive independent association between access to firearms at home and risk of suicide among adults. While two of these studies ${ }^{33}{ }^{34}$ found firearm ownership to be independent of risk of suicide, three regional and two national studies have linked household access to firearms with the risk of suicide..$^{735-37}$ These findings among adults are further corroborated by studies of adolescents that have uniformly found a positive association between access to firearms at home and risk of suicide..$^{38-44}$

Even more convincingly, individual level studies that have specifically examined firearm related suicides uniformly report a positive association between household access to firearms and risk of suicide by firearms. Regional studies have found that adults' risk of suicide by firearm is 3 to 12 times higher among handgun purchasers as compared with controls. ${ }^{30-32}$ Similarly, adolescents with access to firearms at home are four times as likely to commit suicide by firearm than other adolescents. ${ }^{39}$ Most persuasively, in a nationally representative sample, household access to firearms was associated with a 17-fold increase in the risk of suicide by firearm relative to those without such access. ${ }^{8}$

Despite the ubiquity of firearms in several nations across the globe and the abundant evidence linking access to firearms at home with the risk of violent death-particularly suicide by firearm-information on factors that may protect against household members' risk of suicide by firearm (for example, placement of lock triggers) is conspicuously sparse, and the sum of the available information is inconclusive. Seven studies have examined the link between risk of suicide and the manner in which firearm(s) are stored (table 3). In two studies of adult suicide victims and community controls, unsafe firearm storage independently predicted suicide. ${ }^{36}{ }^{37} \mathrm{In}$ a study comparing seven adolescent suicide victims with no apparent psychopathology to 60 suicide victims with a psychiatric disorder and 38 community controls with no disorder, the presence of a loaded firearm in the home was significantly associated with suicide completion. ${ }^{43}$ In four other studies, risk of suicide among adolescents was independent of the manner in which firearms were stored in their residences. ${ }^{38} 394142$ While these studies provide useful preliminary information, they are limited by their focus on small geographical areas, small sample sizes, and in some instances, under-representation of racial and ethnic minorities (see Miller and Hemenway ${ }^{45}$ and Brent ${ }^{46}$ for reviews). These studies are further compromised by not considering study participants' intention to die.

Here we present the first study to address these shortcomings by using a nationally representative sample to estimate the protective effect of storing firearms locked and/ or unloaded. We greatly, but not completely, reduce the bias introduced when intention to die is not considered by including in the analyses proxies for intention to die. Furthermore, our focus is on suicides that are likely to have been impulsive. There is compelling evidence that a considerable proportion of suicides are impulsive acts. 
Table 1 Ecological studies of the link between firearm availability and suicide

\begin{tabular}{|c|c|c|c|}
\hline Authors & $\begin{array}{l}\text { Unit of analysis/ population and } \\
\text { measure of suicide }\end{array}$ & Measure of firearm availability & Findings \\
\hline $\begin{array}{l}\text { Birckmayer and Hemenway, } \\
2001^{22}\end{array}$ & $\begin{array}{l}\text { Suicide and firearm suicide rates } \\
\text { in } 9 \text { US census regions (1979-94) }\end{array}$ & $\begin{array}{l}\text { Proportion of households with } \\
\text { firearms }\end{array}$ & $\begin{array}{l}\text { Prevalence of household firearm ownership } \\
\text { predicted firearm suicide rate. }\end{array}$ \\
\hline Clarke and Jones, $1989^{15}$ & $\begin{array}{l}\text { US suicide and firearm suicide rates } \\
\text { (1959-84) }\end{array}$ & $\begin{array}{l}\text { Proportion of households with } \\
\text { handguns }\end{array}$ & $\begin{array}{l}\text { Prevalence of handgun ownership predicted } \\
\text { rate of firearm suicides. }\end{array}$ \\
\hline Hemenway and Miller, $2002^{21}$ & $\begin{array}{l}\text { Suicide and firearm suicide rates in } \\
9 \text { US census regions (1988-97) }\end{array}$ & $\begin{array}{l}\text { Proportion of households with } \\
\text { handguns }\end{array}$ & $\begin{array}{l}\text { Household handgun ownership rates predicted } \\
\text { firearm suicide and overall suicide rates. }\end{array}$ \\
\hline Kaplan and Geling, $1998^{13}$ & $\begin{array}{l}\text { Firearm suicide and homicide rates } \\
\text { in } 9 \text { US census regions (1989-91) }\end{array}$ & Prevalence of firearm ownership & $\begin{array}{l}\text { Prevalence of firearm ownership predicted } \\
\text { firearm suicide among white and black men }\end{array}$ \\
\hline Kellermann and Reay, $1986^{\circ}$ & $\begin{array}{l}\text { Number of firearm suicides relative } \\
\text { to all firearm deaths that occurred at } \\
\text { home (King County, Washington: } \\
\text { 1978-83). }\end{array}$ & $\begin{array}{l}\text { Whether a firearm was kept in } \\
\text { the home }\end{array}$ & $\begin{array}{l}\text { For every self protection homicide involving a } \\
\text { firearm kept in the home, there were } 37 \\
\text { suicides involving firearms }\end{array}$ \\
\hline Kellermann et al, $1998^{10}$ & $\begin{array}{l}\text { Number of firearm related attempted } \\
\text { and completed suicides relative to all } \\
\text { shootings in/around a home in three } \\
\text { US cities (Nov 1992-May 1994). }\end{array}$ & $\begin{array}{l}\text { Whether the gun involved was } \\
\text { kept in the home }\end{array}$ & $\begin{array}{l}\text { For every legally justifiable shooting, there } \\
\text { were } 11 \text { attempted or completed suicides }\end{array}$ \\
\hline Killias, $1993^{2}$ & $\begin{array}{l}\text { Proportion of suicides with a firearm, } \\
\text { rate of firearm suicide, and overall } \\
\text { suicide rate in } 14 \text { countries } \\
(1983-86)\end{array}$ & $\begin{array}{l}\text { Proportion of households with } \\
\text { firearms (1989) }\end{array}$ & $\begin{array}{l}\text { Prevalence of household gun ownership } \\
\text { predicted proportion of suicides with a gun, } \\
\text { rate of firearm suicide, and overall suicide rate }\end{array}$ \\
\hline Kleck and Patterson, $1993^{24}$ & $\begin{array}{l}\text { Suicide and firearm suicide rates in } \\
170 \text { US cities (1979-81). }\end{array}$ & $\begin{array}{l}\text { Proportion of firearm related } \\
\text { homicides (1979-82); other crimes } \\
\text { (1979-80), and the dollar value of } \\
\text { stolen property attributable to } \\
\text { firearms thefts (1979-81) }\end{array}$ & $\begin{array}{l}\text { Gun prevalence predicted total suicide and } \\
\text { firearm suicide rates }\end{array}$ \\
\hline Lester, $1988^{16}$ & $\begin{array}{l}\text { Rates of suicide by firearm and } \\
\text { other methods in } 9 \text { US census } \\
\text { regions (1970) }\end{array}$ & $\begin{array}{l}\text { Proportion of homicides and suicides } \\
\text { committed with firearms; accidental } \\
\text { death rate from firearms; state } \\
\text { handgun control laws, and subscription } \\
\text { rates to firearm magazines }\end{array}$ & $\begin{array}{l}\text { States with a higher availability of firearms had } \\
\text { higher firearm suicide rates. }\end{array}$ \\
\hline Lester, $1989^{12}$ & $\begin{array}{l}\text { Suicide and firearm suicide rates } \\
\text { in the } 48 \text { continental US states (1980) }\end{array}$ & $\begin{array}{l}\text { Per capita circulation of Shooting } \\
\text { Times, Guns \& Ammo, and American } \\
\text { Handgunner }\end{array}$ & $\begin{array}{l}\text { States with a higher per capita circulation of } \\
\text { firearm magazines had higher suicide and } \\
\text { firearm suicide rates. }\end{array}$ \\
\hline Lester, $1990^{17}$ & $\begin{array}{l}\text { Suicide rates by firearm and other } \\
\text { methods in } 20 \text { countries }-1980\end{array}$ & $\begin{array}{l}\text { Proportion of homicides committed } \\
\text { by firearms }\end{array}$ & $\begin{array}{l}\text { Proportion of homicides committed by firearms } \\
\text { predicted firearm suicide rate. }\end{array}$ \\
\hline Lester, $2000^{25}$ & $\begin{array}{l}\text { Firearm suicide rates in } 36 \text { nations } \\
\text { (1993) }\end{array}$ & $\begin{array}{l}\text { Accidental firearm mortality rate; } \\
\text { proportion of homicides involving } \\
\text { firearms }\end{array}$ & $\begin{array}{l}\text { Accidental firearm mortality rate was } \\
\text { independent of firearm suicide rate; proportion } \\
\text { of homicides involving firearms predicted } \\
\text { firearm suicide rate. }\end{array}$ \\
\hline Lester, $2001^{27}$ & $\begin{array}{l}\text { Percentage of suicides using firearms } \\
\text { among total Canadian population } \\
\text { (1970-95) }\end{array}$ & $\begin{array}{l}\text { Rate of accidental death from } \\
\text { firearms }\end{array}$ & $\begin{array}{l}\text { Rate of accidental death from firearms } \\
\text { predicted percentage of suicides using firearms } \\
\text { for all age groups except } 55+\text {. }\end{array}$ \\
\hline Bridges, $2002^{28}$ & $\begin{array}{l}\text { Replicated Lester, 2001, using } 3 \\
\text { additional years of data (1996-98) }\end{array}$ & $\begin{array}{l}\text { Rate of accidental death from } \\
\text { firearms }\end{array}$ & $\begin{array}{l}\text { Rate of accidental death from firearms } \\
\text { predicted percentage of suicides using firearms } \\
\text { for all age groups except } 55+\text {. }\end{array}$ \\
\hline Miller et al, $2002^{18}$ & $\begin{array}{l}\text { Suicide and firearm suicide rates } \\
\text { for all US women (1988-97) }\end{array}$ & $\begin{array}{l}\text { Household gun ownership rates; } \\
\text { Cook's Index, and fraction of all } \\
\text { suicides that involved a gun }\end{array}$ & $\begin{array}{l}\text { States with relatively lower availability of } \\
\text { firearms had relatively lower rates of suicides, } \\
\text { and firearm suicides. }\end{array}$ \\
\hline Miller et al, $2002^{23}$ & $\begin{array}{l}\text { Suicide and firearm suicide rates } \\
\text { for all US 5-14 year olds (1988-97) }\end{array}$ & $\begin{array}{l}\text { Household gun ownership rates; } \\
\text { Cook's Index; and fraction of all } \\
\text { suicides that involved a gun }\end{array}$ & $\begin{array}{l}\text { States with relatively lower availability of } \\
\text { firearms had relatively lower rates of suicides, } \\
\text { and firearm suicides. }\end{array}$ \\
\hline Miller et al, $2002^{20}$ & $\begin{array}{l}\text { Suicide and firearm suicide rates } \\
\text { for all US states, } 9 \text { census regions } \\
\text { (1988-97) }\end{array}$ & $\begin{array}{l}\text { Proportion of households with } \\
\text { firearms (NORC); fraction of all } \\
\text { suicides that involved a gun }\end{array}$ & $\begin{array}{l}\text { States with relatively lower availability of } \\
\text { firearms had relatively lower rates of suicides, } \\
\text { and firearm suicides. }\end{array}$ \\
\hline
\end{tabular}

Internationally, $24 \%$ to $53 \%$ of suicides are contemplated for as little as five minutes. ${ }^{47-51}$ Clearly, any measure that can prolong the period between the initial decision to commit suicide and the suicidal act can potentially decrease the fleeting intention to die and possibly prevent the suicidal behaviour. Reducing ease of access to firearms through safer storage practices is potentially one such method. Our aim is to estimate the protective effect of safer firearm storage practices (that is, storing firearms locked and/or unloaded) on the risk of suicide by firearm among people with relatively low intention to die.

\section{METHODS}

\section{Sample}

We use data from the 1993 National Mortality Followback Survey $\left(\mathrm{NMFS}^{52}\right)$. This is a survey of social, medical, and lifestyle practices of the decedent as reported by the next of kin (hereafter, informant). The 1993 NMFS is based on a sample of 22957 deaths representing 2215000 people. A $10 \%$ random sample of death certificates from all states in the union (except South Dakota), and independent vital registration areas of the District of Columbia and New York City were drawn from the 1993 Current Mortality Sample. Informants were identified either on the death certificate as having provided information or were identified by the funeral director. When an informant was not identified in this manner or could not be located, another person familiar with the decedent's life history was recruited by personalised letter. Eighty three per cent of informants participated in the survey.

To reduce the likelihood of misinformation provided by respondents not well acquainted with the decedent, we included in the analyses only information reported by the spouse $(38 \%)$, parent $(32 \%)$, sibling $(14 \%)$, or offspring $(14 \%)$. As an added precaution, we further focused the study sample to decedents who had resided with their informant 
Table 2 Individual level studies of the link between firearm availability and suicide

\begin{tabular}{|c|c|c|c|c|}
\hline Authors & $\begin{array}{l}\text { Number of suicide victims } \\
\text { (cases)** }\end{array}$ & Comparison group & Outcome assessed/exposure & OR $(\mathrm{Cl}) t / p$ value \\
\hline \multicolumn{5}{|c|}{ (A) Adult individual level studies } \\
\hline Bailey et al, $1997^{7}$ & 120 females & $\begin{array}{l}120 \text { matched community } \\
\text { dwelling controls }\end{array}$ & $\begin{array}{l}\text { RS among women/ } \geqslant \text { one gun in } \\
\text { home }\end{array}$ & $4.6(1.2$ to 17.5$)$ \\
\hline $\begin{array}{l}\text { Beautrais et al., } \\
1996^{34}\end{array}$ & 197 & $\begin{array}{l}1028 \text { community dwelling } \\
\text { controls }\end{array}$ & RS/access to a firearm at home & $1.4(0.96$ to 1.99$)$ \\
\hline $\begin{array}{l}\text { Conwell et al, } \\
2002^{37}\end{array}$ & 86 , ages 50 and over & $\begin{array}{l}86 \text { matched community } \\
\text { dwelling controls }\end{array}$ & $\mathrm{RS} / \geqslant$ one gun in home & $3.23(1.15$ to 11.20$)$ \\
\hline $\begin{array}{l}\text { Cummings et al, } \\
1997^{30}\end{array}$ & 353 & $\begin{array}{l}1756 \text { matched community } \\
\text { dwelling controls }\end{array}$ & $\begin{array}{l}\text { RS/history of family handgun } \\
\text { purchase }\end{array}$ & $1.9(1.4$ to 2.5$)$ \\
\hline $\begin{array}{l}\text { Grassel et al, } \\
2003^{32}\end{array}$ & $\begin{array}{l}887 \text { suicide victims and } \\
1546 \text { gun suicide victims }\end{array}$ & 208738 non-injury deaths & $\begin{array}{l}\text {-RS } \\
\text {-RFS/handgun purchase }\end{array}$ & $\begin{array}{l}6.8(5.7 \text { to } 8.1) \\
12.5(10.4 \text { to } 15.0)\end{array}$ \\
\hline $\begin{array}{l}\text { Kellermann et al, } \\
1992^{36}\end{array}$ & 438 & $\begin{array}{l}438 \text { matched community } \\
\text { dwelling controls }\end{array}$ & $\mathrm{RS} / \geqslant$ one gun in home & $4.8(2.7$ to 8.5$)$ \\
\hline Kung et al, $2003^{35}$ & 22772 & $\begin{array}{l}448710 \text { decedents with natural } \\
\text { causes of death }\end{array}$ & $\begin{array}{l}\text { RS/any firearms in or around } \\
\text { decedent's home during last } \\
\text { year of life }\end{array}$ & $\begin{array}{l}\text { Men living with others } \\
3.53(2.42 \text { to } 5.15) \\
\text { Women living with others } \\
2.99 \text { (1.58 to } 5.65)\end{array}$ \\
\hline Wiebe, $2003^{8}$ & 1959 & $\begin{array}{l}13535 \text { community dwelling } \\
\text { controls }\end{array}$ & $\begin{array}{l}\text {-RS } \\
\text {-RFS/having a gun in home }\end{array}$ & $\begin{array}{l}3.44(3.06 \text { to } 3.86) \\
16.89(13.26 \text { to } 21.52)\end{array}$ \\
\hline $\begin{array}{l}\text { Wintemute et al, } \\
1999^{31}\end{array}$ & $\begin{array}{l}238,292 \text { handgun purchasers } \\
\text { in California-observed } \\
1991-1996\end{array}$ & $\begin{array}{l}\text { General adult population of } \\
\text { California }\end{array}$ & $\begin{array}{l}\text {-RS in first year after handgun } \\
\text { purchase } \\
\text {-RFS in first year after handgun } \\
\text { purchase }\end{array}$ & $\begin{array}{l}\text { SMR } 4.31 \\
\text { SMR } 7.12\end{array}$ \\
\hline \multicolumn{5}{|c|}{ (B) Adolescent individual level studies } \\
\hline Brent et al, $1988^{42}$ & 27 & 56 suicidal psychiatric inpatients & $\mathrm{RS} /$ firearms available in home & $2.7(1.1$ to 6.4$)$ \\
\hline Brent et al, $1991^{41}$ & 47 & $\begin{array}{l}\text { (a) } 47 \text { suicide attempters } \\
\text { (b) } 47 \text { never suicidal psychiatric } \\
\text { controls }\end{array}$ & $\mathrm{RS} /$ gun available in home & $\begin{array}{l}\text { a: } 2.1(1.2 \text { to } 3.7) \\
\text { b: } 2.2(1.4 \text { to } 3.5)\end{array}$ \\
\hline Brent et al, $1993^{38}$ & $\begin{array}{l}\text { 7, all with no apparent } \\
\text { psychopathology }\end{array}$ & $\begin{array}{l}\text { (a) } 60 \text { adolescent suicide victims } \\
\text { with psychiatric disorder } \\
\text { (b) } 38 \text { community controls with } \\
\text { no psychiatric disorder }\end{array}$ & RS/gun available in home & $\begin{array}{l}\text { a: none reported } \\
b: p=0.04\end{array}$ \\
\hline Brent et al, $1993^{43}$ & 67 & $\begin{array}{l}67 \text { matched community dwelling } \\
\text { controls }\end{array}$ & $\mathrm{RS} /$ any gun available in the home & $3.3(1.4$ to 7.7$)$ \\
\hline Brent et al, $1994^{44}$ & $\begin{array}{l}63 \text {, all with a history of } \\
\text { affective illness }\end{array}$ & $\begin{array}{l}23 \text { community dwelling controls } \\
\text { with a history of affective illness }\end{array}$ & $\mathrm{RS} /$ handgun available in the home & $p<0.01$ \\
\hline Brent et al, $1999^{40}$ & 140 & 131 community dwelling controls & $\mathrm{RS} /$ gun in home & $4.00(1.30$ to 14.70$)$ \\
\hline Shah ef al, $2000^{39}$ & 36 firearm suicide victims & $\begin{array}{l}36 \text { matched community dwelling } \\
\text { controls }\end{array}$ & RFS/household access to firearms & $3.91(1.11$ to 13.80$)$ \\
\hline
\end{tabular}

for at least a year. To focus on impulsive suicides, we further focused our study sample to decedents who, according to the informant, had not expressed a wish to die during the last month of life. Finally, the study sample included only records with complete information on all variables of interest.
Recognising that there may be residual confounding by intention to die, we identified two groups in addition to the study sample just described. The first group is comprised of decedents who did not have any of the three strongest correlates of suicide (other than demographics) in the study

Table 3 Studies of firearm storage practices and suicide risk

\begin{tabular}{|c|c|c|c|c|}
\hline Authors & Cases & Controls & Measures of firearm storage & Odds ratio $(\mathrm{Cl})^{*} / \mathrm{p}$ value \\
\hline Brent et al, $1988^{42}$ & 27 & 56 suicidal psychiatric inpatients & $\begin{array}{l}\text { Firearms stored loaded } \\
\text { Firearms stored locked }\end{array}$ & $\begin{array}{l}\text { NSt } \\
\text { NSt }\end{array}$ \\
\hline Brent et al, $1991^{41}$ & 47 & $\begin{array}{l}\text { (a) } 47 \text { suicide attempters } \\
\text { (b) } 47 \text { never suicidal psychiatric } \\
\text { controls }\end{array}$ & $\begin{array}{l}\text { Guns stored locked } \\
\text { Guns stored together } \\
\text { with ammunition } \\
\text { Guns stored loaded }\end{array}$ & $\begin{array}{l}\text { NSt } \\
\text { NSt } \\
\text { NS† }\end{array}$ \\
\hline Brent ef al, $1993^{38}$ & $\begin{array}{l}\text { 7, all with no apparent } \\
\text { psychopathology }\end{array}$ & $\begin{array}{l}\text { (a) } 60 \text { adolescent suicide victims } \\
\text { with psychiatric disorder } \\
\text { (b) } 38 \text { community controls with no } \\
\text { psychiatric disorder }\end{array}$ & Loaded gun in the home & $\begin{array}{l}\text { Cases } v \text { a: } p<0.01 \\
\text { Cases } v \text { b: } p<0.01\end{array}$ \\
\hline Brent et al, $1993^{43}$ & 67 & $\begin{array}{l}67 \text { matched community dwelling } \\
\text { controls }\end{array}$ & Loaded gun in the home & NSt \\
\hline $\begin{array}{l}\text { Conwell et al, } \\
2002^{37}\end{array}$ & 86 , ages 50 and over & $\begin{array}{l}86 \text { matched community dwelling } \\
\text { controls }\end{array}$ & $\begin{array}{l}\geqslant 1 \text { gun kept unlocked } \\
\geqslant 1 \text { gun kept loaded }\end{array}$ & $\begin{array}{l}9.52(1.52 \text { to } 58.82) \\
6.41(1.17 \text { to } 35.71)\end{array}$ \\
\hline $\begin{array}{l}\text { Kellermann et al, } \\
1992^{36}\end{array}$ & 438 & $\begin{array}{l}438 \text { matched community dwelling } \\
\text { controls }\end{array}$ & $\begin{array}{l}\text { Any gun kept loaded } \\
\text { All guns kept unloaded } \\
\text { Any gun kept unlocked } \\
\text { All guns kept locked up }\end{array}$ & $\begin{array}{l}9.2(4.1 \text { to } 20.1) \\
3.3(1.7 \text { to } 6.1) \\
5.6(3.1 \text { to } 10.4) \\
2.4(1.0 \text { to } 5.7)\end{array}$ \\
\hline Shah et al, $2000^{39}$ & 36 firearm suicide victims & $\begin{array}{l}36 \text { matched community dwelling } \\
\text { controls }\end{array}$ & $\geqslant 1$ unlocked gun in the home & $\begin{array}{l}p=0.05 \\
\text { Crude OR } 2.57 \text { (0.98 to } 6.70 \text { ) }\end{array}$ \\
\hline
\end{tabular}


Table 4 Descriptive statistics by cause of death

\begin{tabular}{|c|c|c|c|}
\hline Decedent's characteristics & $\begin{array}{l}\text { Study sample } \\
(\mathrm{n}=4996 \text { ) }\end{array}$ & $\begin{array}{l}\text { Committed suicide } \\
\text { by firearm } \\
\text { ( } n=190)\end{array}$ & $\begin{array}{l}\text { Died from other } \\
\text { causes } \\
(n=4806)\end{array}$ \\
\hline \multicolumn{4}{|l|}{ Sociodemographic characteristics } \\
\hline Mean age, y (SE) & $70.9(0.4)$ & $50.3(1.4)$ & $71.0(0.4)^{*}$ \\
\hline Male, $\%$ & 57.1 & 87.3 & $56.9^{*}$ \\
\hline \multicolumn{4}{|l|}{ Education, \% } \\
\hline Less than high schoolt & 38.0 & 35.8 & 38.0 \\
\hline High school & 35.6 & 40.0 & 35.6 \\
\hline College & 26.3 & 24.1 & 26.3 \\
\hline \multicolumn{4}{|l|}{ Race/ethnicity, \% } \\
\hline White non-Hispanic and other† & 87.1 & 84.7 & 87.1 \\
\hline Black non-Hispanic & 10.7 & 9.4 & 10.7 \\
\hline Hispanic & 2.2 & 6.0 & $2.2^{*}$ \\
\hline \multicolumn{4}{|l|}{ Region of residence } \\
\hline Northeast† & 17.2 & 9.7 & $17.2^{*}$ \\
\hline Midwest & 29.8 & 23.5 & 29.8 \\
\hline South & 34.6 & 49.3 & $34.5^{*}$ \\
\hline West & 18.5 & 17.5 & 18.5 \\
\hline \multicolumn{4}{|l|}{$\begin{array}{l}\text { Correlates of mental wellbeing and stress } \\
\text { Frequency engaged in religious activities, \% }\end{array}$} \\
\hline Nevert & 37.0 & 57.2 & $36.9^{*}$ \\
\hline $\begin{array}{l}\text { Less than once per month, } 1-3 \text { times per month, } \\
1-2 \text { times per week }\end{array}$ & 56.2 & 36.5 & $56.3^{*}$ \\
\hline 3-6 times per week, every day & 6.8 & 6.3 & 6.8 \\
\hline \multicolumn{4}{|l|}{$\begin{array}{l}\text { Frequency engaged in moderate/vigorous physical } \\
\text { activities, \% }\end{array}$} \\
\hline Nevert & 45.1 & 22.2 & $45.2^{*}$ \\
\hline Less than once per month, 1-3 times per month, & & & \\
\hline $1-2$ times per week & 19.9 & 22.7 & 19.9 \\
\hline 3-6 times per week, every day & 35.0 & 55.1 & $34.9^{*}$ \\
\hline \multicolumn{4}{|l|}{ Frequency of contact with family or friends, $\%$} \\
\hline Nevert & 5.3 & 3.9 & 5.3 \\
\hline Less than once per month, 1-3 times per month, & & & \\
\hline $1-2$ times per week & 24.6 & 23.0 & 24.6 \\
\hline 3-6 times per week, every day & 70.1 & 73.1 & 70.1 \\
\hline Consumed $1+$ alcoholic drinks per occasion, \%‡ & 24.2 & 58.9 & $24.0^{*}$ \\
\hline Experienced employment change, \% & 1.6 & 17.1 & $1.5^{*}$ \\
\hline Avoided or refused needed health care, $\%$ & 14.2 & 22.5 & $14.2^{*}$ \\
\hline Visited a psychiatrist/psychologist, $\%$ & 4.9 & 14.5 & $4.8^{*}$ \\
\hline \multicolumn{4}{|l|}{ Number of depressive symptoms, \%§ } \\
\hline None† & 23.3 & 32.1 & $23.2^{*}$ \\
\hline $1-2$ & 34.9 & 27.6 & $34.9^{*}$ \\
\hline $3-4$ & 25.0 & 24.5 & 25.0 \\
\hline $5+$ & 16.9 & 15.9 & 16.9 \\
\hline \multicolumn{4}{|l|}{ Possession and storage of firearms } \\
\hline Firearm(s) kept in/around the home, $\%$ & 35.7 & 91.3 & $35.4^{*}$ \\
\hline Firearm(s) kept locked, \%‡ & 43.3 & 29.1 & 43.5 \\
\hline Firearm(s) kept unloaded, \%‡ & 81.2 & 61.8 & $81.4^{*}$ \\
\hline \multicolumn{4}{|c|}{$\begin{array}{l}\text { Source: } 1993 \text { National Mortality Followback Survey (NMFS). †Reference group. †Reference group is non- } \\
\text { drinkers, which includes lifetime abstainers and former drinkers. §Depressive symptoms include: (1) seeming } \\
\text { drowsy or sluggish, (2) seeming unresponsive or withdrawn, (3) seeming impatient or annoyed, (4) expressing } \\
\text { feelings of worthlessness, (5) crying for long periods for no apparent reason, (6) having trouble sleeping or } \\
\text { sleeping more or less than usual, ( } 7 \text { ) eating more or less than usual, and (8) having trouble concentrating or } \\
\text { difficulty making decisions. "Statistics are presented only for those who own firearms ( } n=1608 \text { ). " } p<0.05-\text { test of } \\
\text { difference between those who committed suicide by firearm and those who died from other causes. }\end{array}$} \\
\hline
\end{tabular}

sample: (1) consumed alcohol in the last year of life, (2) experienced an employment change in the last year of life, and (3) visited a mental health professional in the last year of life. The second group is comprised of only suicide victims. We reasoned that, on average, compared with the study sample, intention to die is relatively lower among decedents who did not have any of the three strongest correlates of suicide, and relatively higher among those who died of suicide. Thus, for this analysis, we make the simplifying assumption that if the risk associated with unsafe firearm storage is highest among those with the highest intention to die, and lowest among those with the lowest intention to die, then we have reasonably succeeded to group decedents by, and partially control for, their intention to die within limitations imposed by the data.

\section{Measurement}

The dependent variable in this study is an indicator of whether the decedent committed suicide with a firearm according to the cause of death stated on the death certificate. Use of firearms in the suicide was determined based on the following ICD-9 codes for external cause of injury (E-codes): E955.0 (suicide by handgun) and E955.1E955.4 (suicide by all other and unspecified firearms)* The primary exposures of interest are whether the decedent kept any firearm(s) in or around home during the last year of life, and whether the firearms were stored unloaded and/or locked in the decedent's home. We consider firearms stored in a locked drawer, cabinet, or closet and those stored with a trigger lock or other locking mechanism as locked, and disassembled firearms to be unloaded.

The regression models include the following variables that refer to the last year of life, except where, as will be noted, the question refers to the last month of life.

*In the NMFS, suicide by airgun (E955.6) was included in a category containing E-codes E954, E955.5-E959, and therefore could not be classified with suicides by firearm. 
Table 5 Logistic regression models of the risk of suicide by firearm relative to death from other causes

\begin{tabular}{|c|c|c|}
\hline \multirow[b]{2}{*}{ Decedent's characteristics } & \multirow{2}{*}{$\begin{array}{l}\text { (A) Study sample } \\
\text { OR }(95 \% \mathrm{Cl})\end{array}$} & \multirow{2}{*}{$\begin{array}{l}\text { (B) Only firearm owners } \\
\text { OR }(95 \% \mathrm{Cl})\end{array}$} \\
\hline & & \\
\hline \multicolumn{3}{|l|}{ Sociodemographic characteristics } \\
\hline Age & $0.96(0.95$ to 0.96$)$ & $0.96(0.95$ to 0.97$)$ \\
\hline \multicolumn{3}{|l|}{ Gender } \\
\hline Female* & 1.00 & 1.00 \\
\hline Male & $2.75(1.82$ to 4.13$)$ & 1.85 (1.09 to 3.14$)$ \\
\hline \multicolumn{3}{|l|}{ Education } \\
\hline Less than high school* & 1.00 & 1.00 \\
\hline High school & $0.88(0.58$ to 1.32$)$ & $1.09(0.60$ to 1.99$)$ \\
\hline College & $0.67(0.40$ to 1.12$)$ & $1.11(0.56$ to 2.20$)$ \\
\hline \multicolumn{3}{|l|}{ Race/ethnicity } \\
\hline White non-Hispanic and other* & 1.00 & 1.00 \\
\hline Black non-Hispanic & $0.51(0.31$ to 0.83$)$ & 0.70 (0.37 to 1.34$)$ \\
\hline Hispanic & $0.94(0.43$ to 2.06$)$ & $2.36(0.84$ to 6.61$)$ \\
\hline \multicolumn{3}{|l|}{ Region of residence } \\
\hline Northeast ${ }^{*}$ & 1.00 & 1.00 \\
\hline Midwest & $1.55(0.80$ to 3.02$)$ & $1.71(0.71$ to 4.14$)$ \\
\hline South & $2.44(1.30$ to 4.60$)$ & $2.63(1.14$ to 6.06$)$ \\
\hline West & $1.32(0.66$ to 2.65$)$ & $0.85(0.34$ to 2.13$)$ \\
\hline \multirow{2}{*}{\multicolumn{3}{|c|}{$\begin{array}{l}\text { Correlates of mental wellbeing and stress } \\
\text { Frequency engaged in religious activities }\end{array}$}} \\
\hline & & \\
\hline \multicolumn{3}{|l|}{$\begin{array}{l}\text { Frequency engaged in religious activities } \\
\text { Never* }^{*}\end{array}$} \\
\hline Less than once per month, $1-3$ times per month, $1-2$ times per week & $0.36(0.25$ to 0.53$)$ & $0.20(0.12$ to 0.34$)$ \\
\hline 3-6 times per week, every day & $0.70(0.37$ to 1.35$)$ & 0.56 (0.23 to 1.37$)$ \\
\hline \multicolumn{3}{|l|}{ Frequency engaged in moderate/vigorous physical activities } \\
\hline Never* ${ }^{*}$ & 1.00 & 1.00 \\
\hline Less than once per month, $1-3$ times per month, $1-2$ times per week & $1.45(0.82$ to 2.57$)$ & $1.05(0.46$ to 2.41$)$ \\
\hline 3-6 times per week, every day & 1.98 (1.14 to 3.44$)$ & $2.83(1.35$ to 5.91$)$ \\
\hline \multicolumn{3}{|l|}{ Frequency of contact with family or friends } \\
\hline Never* ${ }^{*}$ & 1.00 & 1.00 \\
\hline Less than once per month, $1-3$ times per month, $1-2$ times per week & $0.77(0.29$ to 2.00$)$ & $0.89(0.21$ to 3.74$)$ \\
\hline 3-6 times per week, every day & $0.53(0.21$ to 1.35$)$ & $0.49(0.12$ to 2.00$)$ \\
\hline Consumed $1+$ alcoholic drinks per occasion $\dagger$ & $2.38(1.63$ to 3.48$)$ & $2.28(1.33$ to 3.91$)$ \\
\hline Experienced employment change & $4.05(2.29$ to 7.16$)$ & $4.13(2.12$ to 8.05$)$ \\
\hline Avoided or refused needed health care & $1.23(0.78$ to 1.96$)$ & $1.19(0.66$ to 2.17$)$ \\
\hline Visited a psychiatrist/psychologist & $2.75(1.51$ to 5.01$)$ & 5.29 (2.38 to 11.74$)$ \\
\hline \multicolumn{3}{|l|}{ Number of depressive symptoms $\ddagger$} \\
\hline None* $^{*}$ & 1.00 & 1.00 \\
\hline $1-2$ & $0.88(0.55$ to 1.41$)$ & 1.23 (0.65 to 2.33 ) \\
\hline $3-4$ & $1.08(0.63$ to 1.85$)$ & $1.15(0.52$ to 2.51$)$ \\
\hline $5+$ & $0.89(0.48$ to 1.64$)$ & $1.37(0.63$ to 2.99$)$ \\
\hline Number & 4996 & 1608 \\
\hline
\end{tabular}

(1) Sociodemographic characteristics-gender, age, education level, and race/ethnicity ${ }^{53-57}$; US region of residence, ${ }^{13}(2)$ Correlates of mental wellbeing and stress-three categorical variables reflecting the frequency of religious activities, ${ }^{58-61}$ moderate and/or vigorous physical activities (for example, heavy housework, jogging, ), ${ }^{62}$ and interaction with family or friends. ${ }^{61}{ }^{64}$ Also included were indicators of whether or not the decedent consumed alcohol ${ }^{355765}$; experienced a demotion, job loss, quit a job, or retired ${ }^{66-68}$; avoided or refused needed health $\operatorname{care}^{69}{ }^{70}$; or saw a mental health professional. ${ }^{3577}$ Categorical variables reflecting the number of depressive symptoms during the last month of life $\mathrm{e}^{35}$ 71-74 were also included. Up to eight depressive symptoms were

\section{Key points}

- Locked and/or unloaded firearm storage may be effective in reducing impulsive suicidal acts.

- This protective effect is strongest among the majority of suicide victims who engage in impulsive suicidal behaviour. endorsed, allowing a possible range of $0-8$; the $\alpha$ reliability for this scale is 0.77 .

\section{Analysis}

Using logistic regression, we first estimated the risk of suicide by firearm associated with having access to firearm(s) at home, and then estimated the protective effect of safer storage practices among decedents with relatively low, medium, and high intention to die. All covariates deemed relevant based on our review of the literature were simultaneously included in the models. Observations are weighted to account for the study design and for nonresponse of proxy respondents ${ }^{75} 76$ using SUDAAN (version 8.0.1, Research Triangle Institute, Research Triangle Park, $\mathrm{NC}$ ) and the weights provided with the NMFS. ${ }^{52}$

\section{RESULTS}

The study sample consists of 4996 decedents representing 721436 people aged 15 and older. Compared with the original NMFS sample, decedents in our study sample are slightly younger (71 years $v 72$ years) and somewhat overrepresentative of males $(57 \% v 51 \%)$, decedents with a college education $(26 \% \vee 23 \%)$, non-Hispanic whites ( $87 \% \vee 85 \%)$, and residents of the North east $(17 \% v 21 \%)$. Midwestern residents are under-represented (30\% $v 24 \%)$. 
Table 6 Comparison of groups with relatively low, medium, and high intention to die

\begin{tabular}{|c|c|c|c|}
\hline \multirow[b]{3}{*}{ Level of intention to die } & \multirow{3}{*}{$\begin{array}{l}\text { (A) Risk of suicide by firearm at } \\
\text { home relative to death from other causes } \\
\text { OR }(95 \% \mathrm{Cl})\end{array}$} & \multicolumn{2}{|c|}{$\begin{array}{l}\text { (B) Protective effect of safer firearm storage } \\
\text { on risk of suicide by firearm at home }\end{array}$} \\
\hline & & \multirow{2}{*}{$\begin{array}{l}\text { Locked } \\
\text { OR }(95 \% \mathrm{Cl})\end{array}$} & \multirow{2}{*}{$\begin{array}{l}\text { Unloaded } \\
\text { OR }(95 \% \mathrm{Cl})\end{array}$} \\
\hline & & & \\
\hline Group with relatively low intention to die* & $13.98(5.70$ to 34.33$)$ & $0.18(0.06$ to 0.49$)$ & $0.22(0.08$ to 0.57$)$ \\
\hline Study sample (medium intention to die)† & $17.72(10.18$ to 30.85$)$ & $0.39(0.24$ to 0.66$)$ & $0.30(0.18$ to 0.49$)$ \\
\hline Group with relatively high intention to die† & $36.74(14.21$ to 95.00$)$ & $0.87(0.29$ to 2.64$)$ & $0.63(0.18$ to 2.22$)$ \\
\hline
\end{tabular}

Table 4 shows that relative to those who perished because of other causes, decedents who committed suicide by firearm were significantly more likely to be younger ( 50 years $v 71$ years ), male ( $87 \% v 57 \%)$, and Hispanic ( $6 \% v 2 \%)$. They were more likely to have resided in the south $(49 \% v 34 \%)$ and less likely to have resided in the north east ( $10 \% \vee 17 \%)$. Decedents who committed suicide by firearm were more likely to have: never engaged in religious activities $(57 \% \mathrm{v}$ $37 \%)$; exercised frequently ( $55 \% \vee 35 \%)$; consumed alcohol (59\% v 24\%); experienced an employment change (17\% v $2 \%)$; avoided or refused needed health care $(23 \% v 14 \%)$; exhibited fewer depressive symptoms (32\% v 23\%, no symptoms), and visited a mental health professional in the past year ( $14 \% v 5 \%)$. They were also more likely than others to have stored a firearm in/around their residence (91\% $v$ $35 \%)$ and were less likely to keep it unloaded (62\% v $81 \%$ ).

Multivariate analysis of the study sample shows that (table $5(\mathrm{~A})$ ), risk of committing suicide varies by age and gender, but is independent of level of education and race/ ethnicity. Other predictors of suicide by firearm include decedents' alcohol consumption, employment change, and visit(s) to a mental health professional during the last year of life. Among decedents with access to firearms (table 5 (B)), similar associations were found between the risk of suicide by firearm and alcohol consumption, employment change, and visit(s) to mental health professionals. Analysis of the original NMFS sample (analyses not shown) yield similar effect sizes.

Table 6 shows the risk of suicide by firearm relative to death from other causes among decedents in the study sample, as well as among the two groups with relatively lower and higher intention to die. The risk of suicide by firearms is highest among those with the highest intention to die (that is, subsample consisting entirely of suicide victims; $\mathrm{OR}=36.7,95 \% \mathrm{CI}=14.2$ to 95.0 ), medium among those with relatively moderate intention to die (that is, study sample, $\mathrm{OR}=17.7,95 \% \mathrm{CI}=10.2$ to 30.9 ), and lowest among those with the lowest intention to die (that is, subsample excluding those with any of the three strongest correlates of suicide; $\mathrm{OR}=14.0,95 \% \mathrm{CI}=5.7$ to 34.3 ).

The protective effect of safer firearm storage is strongest among those with lowest relative intention to die (locked: $\mathrm{OR}=0.18,95 \% \mathrm{CI}=0.06$ to 0.49 ; unloaded: $\mathrm{OR}=0.22,95 \%$ $\mathrm{CI}=0.08$ to 0.57$)$ and medium among those with relatively moderate intention to die (locked: $\mathrm{OR}=0.39,95 \% \mathrm{CI}=0.24$ to 0.66 ; unloaded: $\mathrm{OR}=0.30,95 \% \mathrm{CI}=0.18$ to 0.49$)$. Among

\section{Policy implications}

Implementation of federally mandated safety standards can help reduce the risk of impulsive firearm related suicides. those with the strongest intention to die, there is no association between safer firearm storage and risk of suicide by firearm.

\section{DISCUSSION}

In line with previous research (for example, Krug et al, ${ }^{53}$ Blakely et al, ${ }^{77}$ Shenassa $\mathrm{et} \mathrm{al}^{78}$ ), we found an increased risk of suicide among males, more frequent drinkers, and persons with recent employment changes. Also in accord with previous works, ${ }^{780-3236-44}$ we found that household access to firearms is associated with an increased risk of suicide by firearm. Decedents with access to firearms at home were 18 times as likely to commit suicide by a firearm than to die from other causes. This points to the importance of factors that may protect against the risk of suicide among populations with access to firearms at home. In this first study to analyse the protective effect of safer firearm storage practices in a nationally representative sample, we found that firearm owners who keep their firearms locked or unloaded were at least $60 \%$ less likely to die from firearm related suicide than those who store their firearms unlocked and/or loaded.

These findings must be considered in light of the study's limitations and strengths. One shortcoming of this study regards the assumption that household firearm ownership is a reliable proxy for firearm access. Evidence suggests that considering firearm ownership alone is likely to miss some decedents with ready access to firearms, but not necessarily at home. ${ }^{79}$ Thus, these analyses may have underestimated the proportion of decedents with ready access to a firearm. This underestimation was probably more prevalent among decedents who did not die of a firearm related injury. This would result in a degree of overestimation of our odds ratios, as it is likely that some members of the comparison groups have had easy access to firearms. However, it is highly unlikely that the large effect size can be explained away by this potential source of misclassification.

We partially addressed one important limitation of existing literature on suicide and firearms by using proxies for decedents' intention to die. We examined three groups that, on average, had relatively high, medium, and low intention to die. As expected, access to firearms at home was most lethal among decedents with highest intention to die, for whom safer firearm storage practices were not protective. For the group with the moderate intention to die, access to firearms at home was moderately lethal, as was the protective effect of keeping firearms locked or unloaded. The most striking results regard the group with the lowest relative intention to die. For this group, access to firearms at home is associated with relatively low risk of suicide by firearms, while the protective effect of storing firearms locked and/or unloaded was greatest. Considering that all those with a stated intention to die were excluded from the study, and considering that this group excludes those with any of the three strongest correlates of suicide, it appears that the 
decedents in this group had a fairly low intention to die and may have engaged in an impulsive act. This suggests that safer firearm storage may be most effective in reducing impulsive suicidal acts.

Our findings are most generalisable to populations with low to moderate intention to die. However, even among those who are highly motivated to die, ${ }^{80} 81$ lack of access to firearms can lower suicide mortality. Even if all of those who committed suicide by firearm simply switched to the next most lethal method, still a significant reduction in suicide mortality would occur. ${ }^{78}$

Our findings further support the utility of devices intended to reduce unauthorised or impulsive use of firearms, including various types of locks and personalisation technology, ${ }^{82-87}$ and the need for a consumer product regulation approach to reducing firearm related injuries and

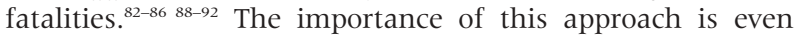
more evident when considering the difficulty of changing individuals' firearm storage practices, ${ }^{82-87} 93$ and the failure of otherwise safety conscious people to store their firearms safely. ${ }^{94-97}$ Although firearm training has frequently been proposed as a means of promoting safer firearm storage, information on the effectiveness of these programmes is sparse. At least two community based programmes appear to have improved firearm storage practices by distributing gun locks or safes to firearm owners. ${ }^{98}{ }^{99}$ In contradiction, a nationally representative survey of firearm owners suggests that receiving firearm training may actually predict unsafe storage practices, ${ }^{5}$ and at least one intervention in a paediatric primary care setting did not promote safer firearm storage. ${ }^{100}$ Thus, as it is currently provided, the efficacy of firearm training in regard to firearm storage practices is questionable.

Internationally, the World Health Organisation has called for greater emphasis on passive approaches to suicide prevention. ${ }^{101}$ Although our findings and recommendations are most directly applicable in nations with higher levels of per capita firearm ownership, such as Australia, Finland, Germany, Guinea, New Zealand, Sweden, the United States, and Russia, ${ }^{101} 102$ they also underscore the importance of policies that make unauthorised and impulsive use of firearms less likely in countries with strict gun control policies. In these countries, efforts to increase the safety of firearm storage among those who keep firearms at home, such as members of military, is still warranted. ${ }^{103}$

In the US, legislation mandating minimum safety features on new firearms can be an essential part of the solution, one that is supported by the vast majority of American adults. ${ }^{104}$ Currently, minimum safety criteria exist for handguns imported into the US. ${ }^{105}$ However, the net effect of these criteria is modest given that they do not apply to firearms manufactured within the US, and they are, alone, not enough to ensure that safety features are consistently applied to new handguns. ${ }^{105}$ Clearly, implementing federally mandated safety standards may be necessary to reduce the risk of violent death associated with firearm ownership. And to the extent that changes in the legal and social milieu are lasting, they are likely to reduce the suicide risk of future generations. ${ }^{106} 107$

\footnotetext{
Authors' affiliations

E D Shenassa, K L Spalding, Department of Community Health, Brown Medical School, Providence, USA

E D Shenassa, M L Rogers, M B Roberts, Centers for Behavioral and Preventive Medicine, Brown Medical School and the Miriam Hospital, Providence, USA

Funding: none.

Conflicts of interest: none declared.
}

\section{REFERENCES}

1 United Nations Economic and Social Council, Commission on Crime Prevention and Criminal Justice. Criminal justice reform and strengthening of legal institutions: measures to regulate firearms. Report of the SecretaryGeneral. 25 Apr 1997. E/CN.15/1997/4.

2 Killias M. International correlations between gun ownership and rates of homicide and suicide. Can Med Assoc J 1993;148:1721-5.

3 Blendon RJ, Young JT, Hemenway D. The American public and the gun control debate. JAMA 1996;275:1719-22.

4 Young JT, Hemenway D, Blendon RJ, et al. Trends: guns. Public Opinion Quarterly 1996:60:634-49.

5 Hemenway D, Solnick SJ, Azrael DR. Firearm training and storage. JAMA 1995;273:46-50.

6 Kellermann AL, Reay DT. Protection or peril? An analysis of firearm-related deaths in the home. N Engl J Med 1986:314:1557-60.

7 Bailey JE, Kellermann AL, Somes GW, et al. Risk factors for violent death of women in the home. Arch Intern Med 1997; 157:777-82.

8 Wiebe DJ. Homicide and suicide risks associated with firearms in the home: a national case-control study. Ann Emerg Med 2003;41:771-82.

9 Miller M, Azrael D, Hemenway D. Rates of household firearm ownership and homicide across US regions and states, 1988-1997. Am J Public Health 2002;92:1988-93.

10 Kellermann AL, Somes G, Rivara FP, et al. Injuries and deaths due to firearms in the home. J Trauma 1998:45:263-7.

11 Kellermann AL, Rivara FP, Rushforth NB, et al. Gun ownership as a risk factor for homicide in the home. N Engl J Med 1993;329:1084-91.

12 Lester D. Gun ownership and suicide in the United States. Psychol Med 1989;19:519-21.

13 Kaplan MS, Geling O. Firearm suicides and homicides in the United States: regional variations and patterns of gun ownership. Soc Sci Med 1998;46:1227-33

14 Lester D. Research note: gun control, gun ownership, and suicide prevention. Suicide Life Threat Behav 1988;18:176-80.

15 Clarke RV, Jones PR. Suicide and increased availability of handguns in the United States. Soc Sci Med 1989;28:805-9.

16 Lester D. Firearm availability and the incidence of suicide and homicide. Acta Psychiatr Belg 1988;88:387-93.

17 Lester $\mathbf{D}$. The availability of firearms and the use of firearms for suicide: a study of 20 countries. Acta Psychiatr Belg 1990;81:146-7.

18 Miller M, Azrael D, Hemenway D. Firearm availability and suicide, homicide, and unintentional firearm deaths among women. J Urban Health 2002;79:26-38

19 Kaplan MS, Adamek ME, Geling O, et al. Firearm suicide among older women in the U.S. Soc Sci Med 1997;44:1427-30.

20 Miller M, Azrael D, Hemenway D. Household firearm ownership and suicide rates in the United States. Epidemiology 2002;13:517-24.

21 Hemenway D, Miller M. Association of rates of household handgun ownership, lifetime major depression, and serious suicidal thoughts with rates of suicide across US census regions. Inj Prev 2002;8:313-16.

22 Birckmayer J, Hemenway D. Suicide and firearm prevalence: are youth disproportionately affected? Suicide Life Threat Behav 2001;31:303-10.

23 Miller M, Azrael D, Hemenway D. Firearm availability and unintentional firearm deaths, suicide, and homicide among 5-14 year olds. J Trauma 2002;52:267-75.

24 Kleck G, Patterson EB. The impact of gun control and gun ownership levels on violence rates. Journal of Quantitative Criminology 1993;9:249-87.

25 Lester D. Firearm availability and the use of firearms for suicide and homicide. Percept Mot Skills 2000;91:998.

26 Krug EG, Powell KE, Dahlberg LL. Firearm-related deaths in the United States and 35 other high- and upper-middle-income countries. Int J Epidemiol 1998;27:214-21

27 Lester D. Gun availability and use of guns for murder and suicide in Canada. Psychol Rep 2001;89:624.

28 Bridges FS. Gun availability and use of guns for murder and suicide in Canada: a replication. Psychol Rep 2002;90:1257-8.

29 Sloan JH, Rivara FP, Reay DT, et al. Firearm regulations and rates of suicide: a comparison of two metropolitan areas. N Engl J Med 1990;322:369-73.

30 Cummings P, Koepsell TD, Grossman DC, et al. The association between the purchase of a handgun and homicide or suicide. Am J Public Health 1997;87:974-8.

31 Wintemute CJ, Parham CA, Beaumont JJ, et al. Mortality among recent purchasers of handguns. N Engl J Med 1999:341:1583-9.

32 Grassel KM, Wintemute GJ, Wright MA, et al. Association between handgun purchase and mortality from firearm injury. Inj Prev 2003;9:48-52.

33 Miller M. Geriatric suicide: the Arizona study. Gerontologist 1978;18:488-95.

34 Beautrais AL, Joyce PR, Mulder RT. Access to firearms and the risk of suicide: a case control study. Aust N Z J Psychiatry 1996;30:741-8.

35 Kung HC, Pearson JL, Liu X. Risk factors for male and female suicide decedents ages 15-64 in the United States. Results from the 1993 National Mortality Followback Survey. Soc Psychiatry Psychiatr Epidemiol 2003:38:419-26

36 Kellermann AL, Rivara FP, Somes G, et al. Suicide in the home in relation to gun ownership. N Engl J Med 1992;327:467-72.

37 Conwell Y, Duberstein PR, Connor K, et al. Access to firearms and risk for suicide in middle-aged and older adults. Am J Geriatr Psychiatry 2002;10:407-16.

38 Brent DA, Perper JA, Moritz G, et al. Firearms and adolescent suicide: a community case-control study. Am J Dis Child 1993;147:1066-71. 
39 Shah S, Hoffman RE, Wake L, et al. Adolescent suicide and household access to firearms in Colorado: results of a case-control study. J Adolesc Health 2000;26: 157-63.

40 Brent DA, Baugher M, Bridge J, et al. Age- and sex-related risk factors for adolescent suicide. J Am Acad Child Adolesc Psychiatry 1999;38:1497-505

41 Brent DA, Perper JA, Allman CJ, et al. The presence and accessibility of firearms in the homes of adolescent suicides: a case-control study. JAMA 1991:266:2989-95.

42 Brent DA, Perper JA, Goldstein CE, et al. Risk factors for adolescent suicide: a comparison of adolescent suicide victims with suicidal inpatients. Arch Gen Psychiatry 1988;45:581-8.

43 Brent DA, Perper J, Moritz G, et al. Suicide in adolescents with no apparent psychopathology. J Am Acad Child Adolesc Psychiatry 1993;32:494-500.

44 Brent DA, Perper JA, Moritz G, et al. Suicide in affectively ill adolescents: a case-control study. J Affect Disord 1994;31:193-202.

45 Miller M, Hemenway D. The relationship between firearms and suicide: a review of the literature. Aggression Violent Behav 1999;4:59-75.

46 Brent DA. Firearms and suicide. Ann NY Acad Sci 2001:932:225-39.

47 Williams CL, Davidson JA, Montgomery I. Impulsive suicidal behavior. J Clin Psychol 1980;36:90-4.

48 Williams CL, Sale IM, Wignall A. Correlates of impulsive suicidal behaviour. N Z Med J 1977:85:323-5.

49 Simon OR, Swann AC, Powell KE, et al. Characteristics of impulsive suicide attempts and attempters. Suicide Life Threat Behav 2001;32(suppl 1):49-59.

50 Baca-García E, Diaz-Sastre C, Basurte E, et al. A prospective study of the paradoxical relationship between impulsivity and lethality of suicide attempts. J Clin Psychiatry $2001 ; 62: 560-4$.

51 O'Donnell I, Farmer R, Catalán J. Explaining suicide: the views of survivors of serious suicide attempts. Br J Psychiatry 1996;168:780-6.

52 National Center for Health Statistics. Public use data file documentation: The National Mortality Followback Survey, 1993-Provisional data. ftp:// ftp.cdc.gov/pub/Health_Statistics/NCHS/Dataset_Documentation/NMFS/ (accessed 9 Jun 2003)

53 DeLeo D, Bertolote J, Lester D. Self-directed violence. In: Krug EG Dahlberg LL, Mercy JA, et al, eds. World report on violence and health. Geneva: World Health Organisation, 2002:185-212.

54 Girard C. Age, gender and suicide. American Sociological Review 1993:58:553-74.

55 Moscicki EK. Epidemiology of suicidal behavior. In: Silverman MM, Maris RW, eds. Suicide prevention: toward the year 2000. New York Guilford, 1985.

56 Moscicki EK. Epidemiology of suicidal behavior. Suicide Life Threat Behav 1995;25:22-35

57 Kung KC, Liu X, Juon HS. Risk factors for suicide in Caucasians and in African-Americans: a matched case-control study. Soc Psychiatry Psychiatr Epidemiol 1998;33:155-61.

58 Stack S, Wasserman I. The effect of religion on suicide ideology: an analysis of the networks perspective. Journal for the Scientific Study of Religion 1992;31:457-66.

59 Batson CD, Schoenrade P, Ventis WL. Religion and the individual: a socialpsychological perspective. New York: Oxford University Press, 1993.

60 Nisbet PA, Duberstein PR, Conwell Y, et al. The effect of participation in religious activities on suicide versus natural death in adults 50 and older. J Nerv Ment Dis 2000;188:543-6.

61 Anonymous. Society and culture. In: Goldsmith SK, Pellmar TC Kleinman AM, et al, eds. Reducing suicide: a national imperative. Washington, DC: The National Academies Press, 2002.

62 Fox KR. The influence of physical activity on mental well-being. Public Health Nutr 1999;2:411-18.

63 Dubbert PM. Physical activity and exercise: recent advances and current challenges. J Consult Clin Psychol 2002;70:526-6.

64 Institute of Medicine. Health and behavior: the interplay of biological, behavioral, and societal influences. Washington, DC: National Academy Press, 2001.

65 Anonymous. Psychiatric and psychological factors. In: Goldsmith SK, Pellmar TC, Kleinman AM, et al, eds. Reducing suicide: a national imperative. Washington, DC: The National Academies Press, 2002.

66 Blakely TA, Collings SC, Atkinson J. Unemployment and suicide. Evidence for a causal association? J Epidemiol Community Health 2003;57:594-600.

67 Qin P, Agerbo E, Mortensen PB. Suicide risk in relation to socioeconomic, demographic, psychiatric, and familial factors: a national register-based study of all suicides in Denmark, 1981-1997. Am J Psychiatry 2003; 160:765-72.

68 Platt S. Unemployment and suicidal behaviour: a review of the literature. Soc Sci Med 1984;19:93-115.

69 Farberow NL. Indirect self-destructive behavior: classification and characteristics. In: The many faces of suicide: indirect self-destructive behavior. New York: McGraw-Hill, 1980.

70 Anonymous. Magnitude of the problem. In: Goldsmith SK, Pellmar TC, Kleinman AM, et al, eds. Reducing suicide: a national imperative. Washington, DC: The National Academies Press, 2002.

71 Harris EC, Barraclough B. Suicide as an outcome for mental disorders: a meta-analysis. Br J Psychiatry 1997;170:205-28.

72 Isometsä ET, Henriksson MM, Aro HM, et al. Suicide in major depression. Am J Psychiatry 1994;151:530-6.
73 Angst J, Angst F, Stassen $\mathrm{HH}$. Suicide risk in patients with major depressive disorder. J Clin Psychiatry 1999;60(suppl 2):57-62

74 Lönnqvist JK. Psychiatric aspects of suicidal behaviour: depression. In: Hawton K, van Heeringen K, eds. The international handbook of suicide and attempted suicide. Chichester, UK: Wiley, 2000.

75 Brogan DJ. Software for sample survey data, misuse of standard packages. In: Armitage P, Colton T, eds. Encyclopedia of biostatistics. Vol 5. New York: Wiley, 1998:4167-74

76 Johnson DR, Elliott LA. Sampling design effects: do they affect the analyses of data from the National Survey of Families and Households? J Marr Fam 1998;60:993-1001.

77 Blakely TA, Collings SCD, Atkinson J. Unemployment and suicide. Evidence for a causal association? J Epidemiol Community Health 2003:57:594-600

78 Shenassa ED, Catlin SN, Buka SL. Lethality of firearms relative to other suicide methods: a population based study. J Epidemiol Community Health 2003;57:120-4

79 Ikeda RM, Dahlberg LL, Kresnow M-j, et al. Studying "exposure" to firearms: household ownership v access. Inj Prev 2003:9:53-7.

80 Shah A, Ganesvaran T. Inpatient suicides in an Australian mental hospital. Aust N Z J Psychiatry 1997;31:291-8.

81 Proulx F, Lesage A, Grunberg F. One hundred inpatient suicides. Br J Psychiatry 1997;171:247-50.

82 Frattaroli S, Webster DW, Teret SP. Unintentional gun injuries, firearm design, and prevention: what we know, what we need to know, and what can be done. J Urban Health 2002;79:49-59.

83 Teret SP, Culross PL. Product-oriented approaches to reducing youth gun violence. The Future of Children 2002;12:119-31.

84 Meadows OM. Firearm safety devices. J Pediatr Health Care 2003;17:157-8

85 Siebel BJ. The case against the gun industry. Public Health Rep 2000;115:410-18

86 Vernick JS, Teret SP. A public health approach to regulating firearms as consumer products. University of Pennsylvania Law Review 2000;148:1193-2011

87 Milne JS, Hargarten SW. Handgun safety features: a review for physicians. J Trauma 1999:47:145-50.

88 Freed LH, Vernick JS, Hargarten SW. Prevention of firearm-related injuries and deaths among youth: a product-oriented approach. Pediatr Clin North Am 1998;45:427-38.

89 Hemenway D. Regulation of firearms. N Engl J Med 1998;339:843-5.

90 Wintemute GJ. The relationship between firearm design and firearm violence: handguns in the 1990s. JAMA 1996;275:1749-53.

91 Hemenway D. The public health approach to motor vehicles, tobacco, and alcohol, with applications to firearms policy. J Public Health Policy 2001;22:381-402.

92 Teret SP, Lewin NL. Policy and technology for safer guns: an update. Ann Emerg Med 2003:41:32-4.

93 Brent DA, Baugher M, Birmaher B, et al. Compliance with recommendations to remove firearms in families participating in a clinical trial for adolescent depression. J Am Acad Child Adolesc Psychiatry 2000;39:1220-6.

94 Coyne-Beasley T, McGee KS, Johnson RM, et al. The association of handgun ownership and storage practices with safety consciousness. Arch Pediatr Adolesc Med 2002;156:763-8.

95 Connor SM, Wesolowski KL. They're too smart for that: predicting what children would do in the presence of guns. Pediatrics 2003;111:e109-14.

96 Farah MM, Simon HK, Kellermann AL. Firearms in the home: parental perceptions. Pediatrics 1999;104:1059-63.

97 Schuster MA, Franke TM, Bastian AM, et al. Firearm storage patterns in US homes with children. Am J Public Health 2000;90:588-94

98 Coyne-Beasley T, Schoenbach VJ, Johnson RM. Love our kids, lock your guns: a community-based firearm safety counseling and gun lock distribution program. Arch Pediatr Adolesc Med 2001;155:659-64.

99 Horn A, Grossman DC, Jones W, et al. Community based program to improve firearm storage practices in rural Alaska. Inj Prev 2003;9:231-4

100 Oatis PJ, Fenn Buderer NM, Cummings P, et al. Pediatric practice based evaluation of the prevent firearm injury program. Inj Prev 1999;5:48-52.

101 Leenaars A, Cantor C, Connolly J, et al. Controlling the evironment to prevent suicide: international perspectives. Can J Psychiatry 2000;45:639-44.

102 Fisher H, Dummond A. A call to arms: the emergency physician international perspectives on firearm injury prevention and the Canadian gun control debate. J Emerg Med 1999;17:529-37.

103 Thoresen S, Mehlum L, Moller B. Suicide in peacekeepers: a cohort study of mortality from suicide in 22,275 Norwegian veterans from international peacekeeping operations. Soc Psychiatry Psychiatr Epidemiol 2003;38:605-10

104 Teret SP, Webster DW, Vernick JS, et al. Support for new policies to regulate firearms: results of two national surveys. N Engl J Med 1998:339:813-18.

105 Milne JS, Hargarten SW, Kellermann AL, et al. Effect of current federal regulations on handgun safety features. Ann Emerg Med 2003;41:1-9.

106 Shenassa E. Society, physical health and modern epidemiology. Epidemiology $2001 ; 12: 467-70$.

107 Rose G. The strategy of preventive medicine. New York: Oxford University Press, 1992. 